\title{
Potential of quixaba (Sideroxylon obtusifolium) latex as a milk-clotting agent
}

Anna Carolina da SILVA ${ }^{1}$, Talita Camila Evaristo da Silva NASCIMENTO ${ }^{1}$, Sheylla Araújo da SILVA ${ }^{1}$, Polyanna Nunes HERCULANO ${ }^{2}$, Keila Aparecida MOREIRA ${ }^{1 *}$

\begin{abstract}
There are several obstacles to the use of chymosin in cheese production. Consequently, plant proteases have been studied as possible rennet substitutes, but most of these enzymes are unsuitable for the manufacture of cheese. The aim of this study was to evaluate the potential of latex from Sideroxylon obtusifolium as a source of milk-clotting proteases and to partially characterize the enzyme. The enzyme extract showed high protease and coagulant activities, with an optimal pH of 8.0 and temperature of $55{ }^{\circ} \mathrm{C}$. The enzyme was stable in wide ranges of temperature and $\mathrm{pH}$. Its activity was not affected by any metal ions tested; but was inhibited by phenylmethanesulfonyl fluoride and pepstatin. For the coagulant activity, the optimal concentration of $\mathrm{CaCl}_{2}$ was $10 \mu \mathrm{mol} \mathrm{L}{ }^{-1}$. Polyacrylamide gel electrophoresis showed four bands, with molecular weights between 17 and $64 \mathrm{kDa}$. These results indicate that the enzyme can be applied to the cheese industry.
\end{abstract}

Keywords: proteolytic activity; plant proteases; rennet.

\section{Introduction}

Milk-clotting can occur by two ways, lactic and enzymatic. The enzymatic coagulation of milk is the result of the hydrolysis of peptide bonds of $\mathrm{k}$-casein, in the case of chymosin is between very specific amino acids, phenylalanine- 105 and methionine 106 in bovine milk. Thus, the hydrolysate of $\kappa$-casein is converted into paracasein and glycomacropeptides that precipitate in the presence of calcium ions and are transferred for the aqueous phase, allowing the soluble calcium has access to internal caseins forming a net which entraps fat and water to make the curd. This process is dependent on temperature, $\mathrm{pH}$ and calcium content in milk (PICÓN; MEDINA; NUÑEZ, 1995; PERRY, 2004; KETHIREDFFIPALI; HILL; DALGLEISH, 2010).

Chymosin is the main enzymatic component of calf rennet. It has been used over the years in cheese production due to its high specificity for k-casein and its low proteolytic activity (VISHWANATHA; APPU RAO; SINGH, 2010). However, increases in cheese consumption and production, the high price and reduced supply of rennets, and the ethical issues associated with the use of the enzyme have led to the search for alternative or additional rennet substitutes (AHMED et al., 2009). Recently, plant coagulants have been an area of interest (CHAZARRA et al., 2007).

Plant enzymes are widely studied as potential coagulants in cheese production, including extracts of Cynara scolymus L. (CHAZARRA et al., 2007), Helianthus annuus and Albizia lebbeck (EGITO et al., 2007), Centaur calciptrea (RAPOSO; DOMINGOS, 2008), the flowers of Silybum marianum (CAVALLI et al., 2008) and Jacaratia corumbensis O. Kuntze (DUARTE et al., 2009). A single extract obtained from Cynara cardunculus (L.) is particularly popular (GALAN et al.,
2008) and has been used for centuries in traditional artisanal cheeses, such as those made with sheep milk (PRADOS; PINO; FERNÁNDEZ-SALGUERO, 2007).

Studies were conducted on the milk-clotting activity of proteases in plants from the Brazilian semi-arid region to determine their usefulness in cheese production (DUARTE et al., 2009). Sideroxylon obtusifolium, also known as quixaba, is a lactescent tree native to the Caatinga Northeast and occurs in the floodplain of wetlands and river banks of savanna vegetation in the Northeast, sandbank on the coasts of Ceará and Rio Grande do Sul, in the Pantanal of Mato Grosso, and also very frequent in the São Francisco Valley. Its occurrence is given preferably in clay soils rich in calcium, the distribution is predominantly discontinuous along the area it occupies (LORENZI; MATOS, 2002; SILVA et al., 2012), and is considered a species with medicinal properties (FERRAZ; ALBUQUERQUE; MEUNIER, 2006). The object of this study is to evaluate the potential of quixaba latex as a milk-clotting agent.

\section{Materials and methods}

\subsection{Materials}

The enzyme was extracted from the latex of the plant Sideroxylon obtusifolium, from the city of Gouveia Delmiro, Alagoas State, Brazil. The latex was collected from quixaba stems after the removal of fruit; the latex was dripped into microfuge tubes that were then transported to the CENLAG (UFRPE/ UAG). All reagents used in this study were of analytical grade unless otherwise stated.

\footnotetext{
Received 6/2/2013

Accepted 15/5/2013 (006015)

${ }^{1}$ Unidade Acadêmica de Garanhuns, Universidade Federal Rural de Pernambuco - UFRPE, Av. Bom Pastor, s/n, Boa Vista, CEP 55292-270, Garanhuns, PE, Brasil,

e-mail:moreiralab@yahoo.com.br

${ }_{2}$ Departamento de Morfologia e Fisiologia Animal, Universidade Federal Rural de Pernambuco - UFRPE, Recife, PE, Brasil

${ }^{*}$ Corresponding author
} 


\subsection{Methods}

\section{Preparation of the enzyme extract}

The latex was solubilized in $0.1 \mathrm{M}$ phosphate buffer, $\mathrm{pH}$ 6.0, at a ratio of $1 \mathrm{~g}$ of latex to $100 \mathrm{~mL}$ of solution. This mixture was stirred for one hour at $24{ }^{\circ} \mathrm{C}$ to accelerate solubilization, then filtered through filter paper and frozen at $-20^{\circ} \mathrm{C}$.

\section{Determination of the total protein content in the enzyme extract}

The Bradford method (1976) was used to quantify the total protein content, which was modified to incorporate Brilliant Coomassie Blue. The calibration curve was generated from stock solutions of bovine serum albumin (BSA) in a concentration range of $0-600 \mu \mathrm{g} \mathrm{mL} \mathrm{m}^{-1}$. Solutions were subjected to an absorbance reading at $595 \mathrm{~nm}$ in a spectrophotometer (Biochrom Libra S6 ${ }^{\circledast}$, Cambridge, UK).

\section{Milk-clotting activity}

Milk-clotting activity assay was performed using the method described by Arima, Yu and Iwasaki (1970), with $1.0 \mathrm{~mL}$ of skimmed milk powder $12 \%$ (w/v) solution containing $10 \mu \mathrm{M}$ $\mathrm{CaCl}_{2}$, this milk solution was preheated for 10 minutes in a water bath at $37^{\circ} \mathrm{C}$, and then $100 \mu \mathrm{L}$ of the enzyme extract was added to begin the reaction. The time count was completed when the first milk clots appeared. To visualize the clot forming, the tube was rotated manually from the start time until to the first particles arose. One milk coagulating unit per milliliter $\left(\mathrm{U} \mathrm{mL}^{-1}\right)$ is defined as $400 \mathrm{t}^{-1}$; the amount of enzyme that coagulates the milk in one minute has 400 milk coagulating units. The variable $t$ is the time required for the first clots of milk to form.

\section{Protease activity}

The proteolytic activity assay was developed according to the method described by Alencar et al. (2003), adding 100 $\mathrm{mL}$ of azocasein (1.0\% in Tris- $\mathrm{HCl}$ buffer) to $60 \mu \mathrm{l}$ of enzyme extract. The reaction mixture was incubated for one hour at room temperature. After incubation, the reaction was stopped by adding $480 \mu \mathrm{l}$ of trichloroacetic acid (TCA) to $10 \%(\mathrm{w} / \mathrm{v})$ of the reaction mixture, followed by centrifugation for 5 minutes at $8000 \mathrm{xg}$ and a temperature of $4{ }^{\circ} \mathrm{C}$. After centrifugation, $320 \mu \mathrm{l}$ was removed from the supernatant and added to $560 \mu \mathrm{l}$ of sodium hydroxide $(1 \mathrm{M})$. One unit of activity is equivalent to a change in optical density of $0.01 \mathrm{~nm}$ per minutes at $440 \mathrm{~nm}$.

\section{Effect of pH on enzyme activity and stability}

The optimum $\mathrm{pH}$ for the enzymatic activity of quixaba protease was determined using different buffers at $0.1 \mathrm{M}$ : phosphate buffer ( $\mathrm{pH}$ 5.8-8.0), Tris-HCl buffer ( $\mathrm{pH} 7.0-9.0)$ and carbonate-bicarbonate buffer ( $\mathrm{pH} 9.5-10.7)$. The determination of the enzyme activity was performed as described above. The $\mathrm{pH}$ stability was measured by subjecting the extracts to the same buffers before starting the enzymatic reaction. Aliquots were taken at 30, 60, 90 and 120 minutes to determine the protease activity at each time point.

\section{Effect of temperature on enzyme activity and stability}

The optimum temperature was determined by measuring the protease and milk-clotting activities of the crude extract at different temperatures: $35-80{ }^{\circ} \mathrm{C}$ for protease activity and $30-80{ }^{\circ} \mathrm{C}$ for milk-clotting activity. To determine the thermal stability, the enzyme was subjected to temperatures of $35-70^{\circ} \mathrm{C}$. Aliquots were taken at time points of 0,30,60, 90, 120 and 180 minutes to determine the specific activities. The samples at each time point were subjected to analytical determinations.

\section{The effect of the activation or inhibition of metal ions on the protease activity}

The ions $\mathrm{Mg}^{2+}, \mathrm{Zn}^{2+}, \mathrm{K}^{+}, \mathrm{Mn}^{2+}, \mathrm{Na}^{+}$and $\mathrm{Fe}^{2+}$ were tested for their influence on the activity of the enzyme. Solutions of azocasein (1.0\% in Tris-HCl buffer) were prepared, each containing $10 \mathrm{~mm} \mathrm{~L}^{-1}$ of one ion, and the enzymatic activity was determined as described by Alencar et al. (2003). Calcium was used as a control ion.

\section{Inhibitors}

Inhibition of the enzyme activity was studied by adding the following protease inhibitors to the crude enzyme extract: $100 \mathrm{mM}$ EDTA (ethylenediaminetetraacetic acid), $100 \mathrm{mM}$ PMSF (phenylmethanesulfonyl fluoride), $100 \mathrm{mM}$ iodoacetic acid and $1 \mathrm{mM}$ pepstatin A. Each inhibitor was added to the extract in a $1: 1(\mathrm{v} / \mathrm{v})$ ratio for 30 minutes at $28^{\circ} \mathrm{C}$, followed by the addition of azocasein as previously described to determine the proteolytic activity.

\section{The Effect of the $\mathrm{Ca}^{2+}$ concentration on milk-clotting activity}

To evaluate the effect of the $\mathrm{Ca}^{2+}$ concentration on the milkclotting activity, the assay was performed according to Arima, Yu and Iwasaki (1970). However, different concentrations of $\mathrm{CaCl}_{2}$ were used (1.0, 5.0, 10.0 and $\left.15.0 \mathrm{mM}\right)$.

\section{Polyacrylamide gel electrophoresis}

Polyacrylamide gel electrophoresis was performed according to the method of Laemmli (1970), using gel concentrations of $4.0 \%$ and $15.0 \%$ to achieve separation. The gels were stained for two hours in a solution of Coomassie brilliant blue R-250 and destained with a $0.25 \%$ solution of $45.0 \%$ methanol and $10.0 \%$ acetic acid until the bands could be visualized. The molecular mass of the bands was determined by the software LabImage 1D (Loccus Biotechnology), using phosphorylase b (97 kDa), albumin $(66 \mathrm{kDa})$, ovalbumin $(45 \mathrm{kDa})$, carbonic anhydrase $(30 \mathrm{kDa})$ and trypsin inhibitor $(20.1 \mathrm{kDa})$ as standard proteins (GE healthcare).

\section{Statistical Analysis}

All experiments were performed in triplicate. The results are expressed as mean \pm standard deviation (SD).

\section{Results and discussion}

The enzyme of the quixaba latex strongly coagulated skimmed milk solution within four minutes (which corresponds 
to a specific clotting activity of $917 \mathrm{U} \mathrm{mg}^{-1}$ ), forming a white and firm curd.

Hashim et al. (2011) provided values for coagulant and protease activities, as well as the relationship between the clotting activity study and the protease activity, which is presented in Table 1. The coagulants described by Hashim had a milk coagulation activity lower than that of the quixaba latex. The quixaba protease also had a coagulant activity higher than other plant-derived coagulants and even chymosin, which has long been considered the best clotting enzyme.

The ratio of milk-clotting activity to proteolytic activity (25.38 $\mathrm{U} \mathrm{mg}^{-1}$ ) of quixaba latex was determined. These results show that the ratio of coagulant activity to protease activity in the quixaba latex (5731) is sufficiently high for the commercial production of cheese. This result suggests that the enzyme in the latex of quixaba has a specific clotting activity because there was no excessive hydrolysis of other proteins not related to the coagulation of milk, which could reduce cheese yield and product quality (VASCONCELOS; ARAÚJO; VERRUMABERNARDI, 2004; NEVES-SOUZA; SILVA, 2005; JAROS; SEITLER; RAHM, 2008).

When different $\mathrm{pH}$ values were tested, the enzyme showed the highest protease activity in $0.1 \mathrm{M}$ Tris- $\mathrm{HCl}$ at a $\mathrm{pH}$ of 8.0 and the lowest activity at a $\mathrm{pH}$ of 5.8 , in $0.1 \mathrm{M}$ phosphate buffer. This higher activity at alkaline $\mathrm{pH}$ suggests that the enzyme belongs to a group of proteases that are often used commercially (GUPTA; BEG; LORENZ, 2002). Similar results were observed for the protease in the latex of Streblus asper, which had an optimum $\mathrm{pH}$ of 9.0, keeping it in the alkaline range (TRIPATHI; TOMAR; JAGANNADHAM, 2011). However, a protease from Ficus racemosa showed higher activity at an acidic $\mathrm{pH}$, with $80 \%$ of its activity occurring at a $\mathrm{pH}$ of 4.0 (DEVARAJ; GOWDA; PRAKASH, 2008). A protease from Jacaratia corumbensis $\mathrm{O}$. Kuntze showed greater activity in a nearly neutral $\mathrm{pH}$ range$\mathrm{pH} 6.5$ for the crude extract of the enzyme and $\mathrm{pH} 7.0$ for the purified enzyme (DUARTE et al., 2009).

The optimum temperature for protease activity was $55^{\circ} \mathrm{C}$, and the residual activity was above $50 \%$ for all temperatures tested. These results corroborate Duarte et al. (2009) when testing a protease from the latex of Jacaratia corumbensis O. Kuntze, which had improved protease activity at $55^{\circ} \mathrm{C}$. For a protease from Streblus asper, the optimum temperature was $65{ }^{\circ} \mathrm{C}$ (TRIPATHI; TOMAR; JAGANNADHAM, 2011), and $60^{\circ} \mathrm{C}$ was ideal for a protease from Ficus racemosa (DEVARAJ;

Table 1. Ratio of milk-clotting activity/proteolytic activity of quixaba protease and other coagulants.

\begin{tabular}{lccc}
\hline \multicolumn{1}{c}{ Enzyme } & $\begin{array}{c}\mathrm{SCA}^{\mathrm{a}} \\
\left(\mathrm{U} \mathrm{mg}^{-1}\right)\end{array}$ & $\begin{array}{c}\mathrm{PA}^{\mathrm{b}} \\
\left(\mathrm{U} \mathrm{mg}^{-1}\right)\end{array}$ & $\begin{array}{c}\text { Ratio } \\
\text { SCA/O.D. PA }\end{array}$ \\
\hline Chymosin & 269 & 0.08 & 3363 \\
Rennet from Mucor & 438 & 0.16 & 2738 \\
Papain & 208 & 0.51 & 408 \\
Protease of Ginger & 314 & 0.19 & 1653 \\
Protease of Quixaba & 917 & 0.16 & 5731 \\
\hline
\end{tabular}

aSCA: Specific Clotting Activity, ${ }^{\mathrm{b} P A}$ : Proteolytic Activity, ${ }^{\mathrm{c} O . D .:}$ Optical Density at $440 \mathrm{~nm}$.
GOWDA; PRAKASH, 2008). An enzyme from Capparis spinosa, proteases from Euphorbia amygdaloides (DEMIR et al., 2005) and the enzyme from Synadenium grantii (MENON et al., 2002) all had an optimum temperature of $60^{\circ} \mathrm{C}$. The protease extracted from Calotropis procera showed improved activity between 55 and $60^{\circ} \mathrm{C}$ (DUBEY; JAGANNADHAM, 2003).

The clotting activity was found to be directly proportional to the temperature, which reached $100 \%$ of residual activity at $80^{\circ} \mathrm{C}$. To study the influence of temperature on the milk-clotting activity of extracts from dried artichoke flowers, Chazarra et al. (2007) selected a temperature range of $20-60{ }^{\circ} \mathrm{C}$, and observed that the coagulation time decreased with increasing temperature. A progressive reduction in the clotting times with temperatures increasing from 20 to $40{ }^{\circ} \mathrm{C}$ was reported by other authors (NÁJERA; DE RENOBALES; BARRON, 2003). Nevertheless, other studies have shown that high temperatures hinder the clotting process (DYBOWSKA; FUJIO, 1996). Although changes in salt concentrations are also involved, the primary factor responsible for decreasing the clotting time of milk is a warmer temperature of the complex formed between $\kappa$-casein, $\beta$-lactoglobulin and lactalbumin (BALCONES; OLANO; CALVO, 1996). In the case of "rennet" made using the latex of quixaba, increasing the coagulation temperature from 30 to 80 ${ }^{\circ} \mathrm{C}$ resulted in a progressive reduction of the clotting time, which was even more pronounced between 50 and $80^{\circ} \mathrm{C}$.

When the enzyme stability relative to $\mathrm{pH}$ was tested, the phosphate buffer led the enzyme residual activity to remain below $100 \%$ for 180 minutes at all tested $\mathrm{pH}$ values $(5.8,6.0$ and 7.0). The same result was observed in the other two buffers tested (Tris- $\mathrm{HCl}$ and carbonate-bicarbonate). A progressive decline in residual activity was observed over time for all buffers. Figure 1 illustrates the $\mathrm{pH}$ stability of the enzyme. For the 180 minute reaction, the enzyme remained stable in the $\mathrm{pH}$ range of 5.8 to 10.7 , demonstrating that despite the decline observed in the activity, the enzyme could last 180 minutes with a residual activity exceeding 30\%. According to Demir et al. (2008), pHstable enzymes are advantageous in food production. Papain and bromelain are traditional plant proteases reported to be stable between pH 5.0 and 9.0 (RAO et al., 1998). Coagulants

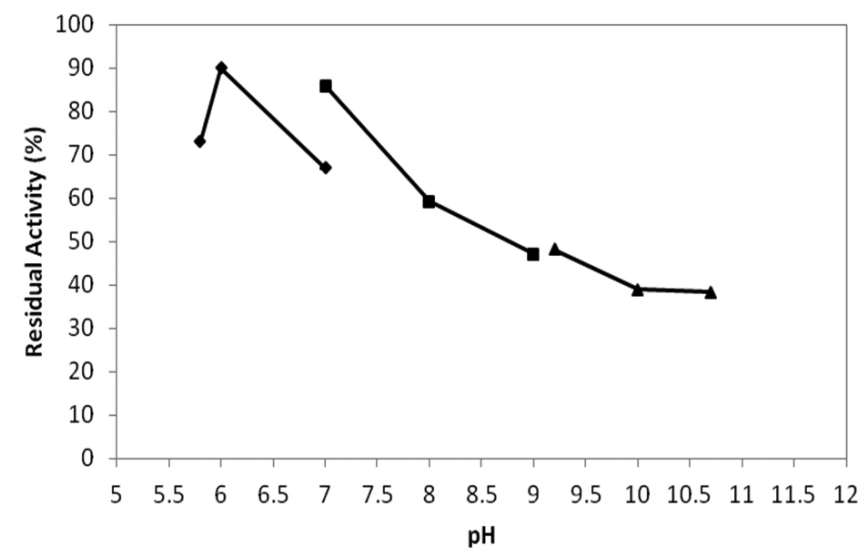

Figure 1. Protease stability curve for $\mathrm{pH}$ over a 180 -minute test. Buffers: $0.1 \mathrm{M}$ phosphate $(\diamond), 0.1 \mathrm{M}$ Tris- $\mathrm{HCl}(\boldsymbol{\bullet})$ and $0.1 \mathrm{M}$ carbonatebicarbonate $(\boldsymbol{\Delta})$. 
should not be sensitive to variations in the $\mathrm{pH}$ of milk because this sensitivity can decrease the yield of cheese or cause defective cheese formation owing to clots too soft for cutting (HARBOE; BUDTZ, 1999).

During the temperature stability test, the protease activity declined over time, showing that the enzyme loses activity when exposed to the tested temperatures for longer periods of time. The enzyme residual activity was higher at temperatures of 35 to $40{ }^{\circ} \mathrm{C}$ and had a residual activity of $115.57 \%$ after 60 minutes at $40{ }^{\circ} \mathrm{C}$. However, the enzyme lost $81.05 \%$ activity by the end of the 180 minute test period at $60{ }^{\circ} \mathrm{C}$.

Figure 2 shows the decrease in activity observed with increasing temperatures over time. These results are similar to those obtained by Duarte et al. (2009) with the protease of Jacaratia corumbensis $\mathrm{O}$. Kuntze, which also lost activity over time at the temperatures tested and was completely inactivated after 90 minutes at $75^{\circ} \mathrm{C}$. These results can also be compared with other studies that did not report a loss of coagulant activity,

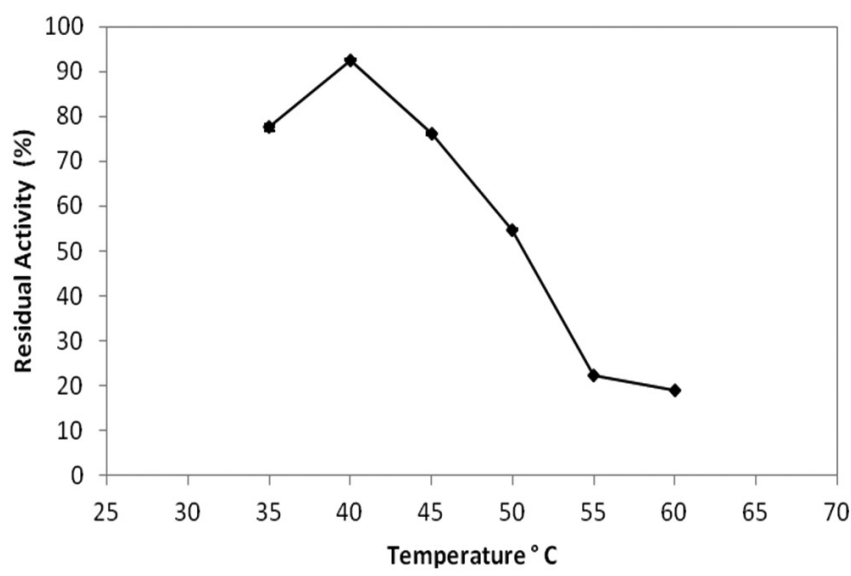

Figure 2. Protease stability curve for temperature over a 180 minute test.

Table 2. Effect of metal ions on protease activity.

\begin{tabular}{cc}
\hline Ions & $\mathrm{RPA}(\%)$ \\
\hline $\mathrm{Ca}^{2+*}$ & $100 \pm 0.151$ \\
$\mathrm{Zn}^{2+}$ & $109.26 \pm 0.264$ \\
$\mathrm{~K}^{+}$ & $127.9 \pm 0.851$ \\
$\mathrm{Mn}^{2+}$ & $106.0 \pm 1.094$ \\
$\mathrm{Na}^{+}$ & $106.3 \pm 0.236$ \\
$\mathrm{Fe}^{2+}$ & $115.5 \pm 0.460$ \\
$\mathrm{Mg}^{2+}$ & $98.1 \pm 0.247$ \\
\hline
\end{tabular}

${ }^{*}$ ): Control; RPA: Residual Protease Activity (\%) \pm SD. such as the crude extract obtained from Solanum dobium that lasted 10 minutes at 40 and $50{ }^{\circ} \mathrm{C}$ (YOUSIF; McMAHON; SHAMMET, 1996). A protease from lettuce was not significantly affected by incubation at $50{ }^{\circ} \mathrm{C}$, as it retained $80 \%$ of its initial protease activity (LO PIERO; PUGLISI; PETRONE, 2002). These results suggest that proteases derived from quixaba latex can be a potential source of enzymes useful in dairy applications.

The metal cations used had no significant effect on protease activity (Table 2). The highest level of enzyme inhibition was $1.9 \%$ by $\mathrm{Mg}^{2+}$, while $\mathrm{K}^{+}$increased the enzyme activity by $27.9 \%$ of the maximum. Many studies have investigated the effect of ions on the physicochemical characteristics of milk-clotting by adding $\mathrm{NaCl}$ or $\mathrm{CaCl}_{2}$ (VAN HOOYDONK; HAGEDOORN; BOERRIGTER, 1986; FOX, 1997), but few have demonstrated that ions had a significant influence (FAMELART; LE GRAET; RAULOT, 1999). These results agree with Moreira et al. (2003), who observed no significant inhibition of the activity of a protease from Nocardiopsis sp. owing to metal ions but determined that the protease activity can be increased in the presence of the $\mathrm{K}^{+}$.

For the concentrations of $\mathrm{CaCl}_{2}$ tested, a concentration of $10 \mu \mathrm{m}$ produced the highest clotting activity $\left(882.10 \mathrm{U} \mathrm{mg}^{-1}\right)$. This is the same concentration suggested by Arima, Yu and Iwasaki (1970) in its methodology for clotting activity. The coagulation stage of milk requires the presence of $\mathrm{Ca}^{2+}$, although the coagulation also depends greatly upon the temperature (ORDÓÑEZ et al., 2005).

The effect of protease inhibitors (Table 3) on enzyme activity was examined. The enzyme was inhibited by PMSF, pepstatin and iodoacetic acid. The lowest activities were observed when iodoacetic acid was included, suggesting the presence of a cysteine protease in the enzyme of the crude extract. The protease of Jacaratia corumbensis $\mathrm{O}$. Kuntze is also a cysteine protease because its activity was inhibited in the presence of iodoacetic acid (DUARTE et al., 2009). The protease of quixaba latex was not inhibited by EDTA, indicating that this protease is not a metalloprotease. In fact, EDTA induced enzyme activation, and the residual protease activity increased to $115 \%$.

The enzyme derived from quixaba latex was analyzed on polyacrylamide gel, revealing four bands with molecular weights of $64,53,20$ and $17 \mathrm{kDa}$ (Figure 3), one of which may be one of the protease of interest. These values were compared to the molecular weights of milk-clotting proteases of plant origin provided by other studies. A study on ginger root obtained an enzyme of $36 \mathrm{kDa}$ (HASHIM et al., 2011), and the Jacaratia corumbensis $\mathrm{O}$. Kuntze protease was $33 \mathrm{kDa}$ (DUARTE et al., 2009). However, it is important to note that these proteases were

Table 3. Enzyme inhibition in the presence of the main protease inhibitors.

\begin{tabular}{lcccc}
\hline \multicolumn{1}{c}{ Inhibitors } & Target Protease & Concentration $(\mathrm{mM})$ & Residual Activity $(\%) \pm$ SD & Inhibition (\%) \\
\hline Control & ----- & ---- & $100 \pm 0.0$ & $-1.67 \pm 0.035$ \\
PMSF & Serine & $100 \mathrm{mM}$ & $115.14 \pm 0.023$ & 88.33 \\
EDTA & Metallo & $100 \mathrm{mM}$ & $4.73 \pm 0.023$ & 0 \\
Pepstatin A & Aspartic & $1 \mathrm{Mm}$ & $2.52 \pm 0.011$ & 95.27 \\
Iodoacetic Acid & Cystein & $100 \mathrm{mM}$ & & 97.48 \\
\hline
\end{tabular}




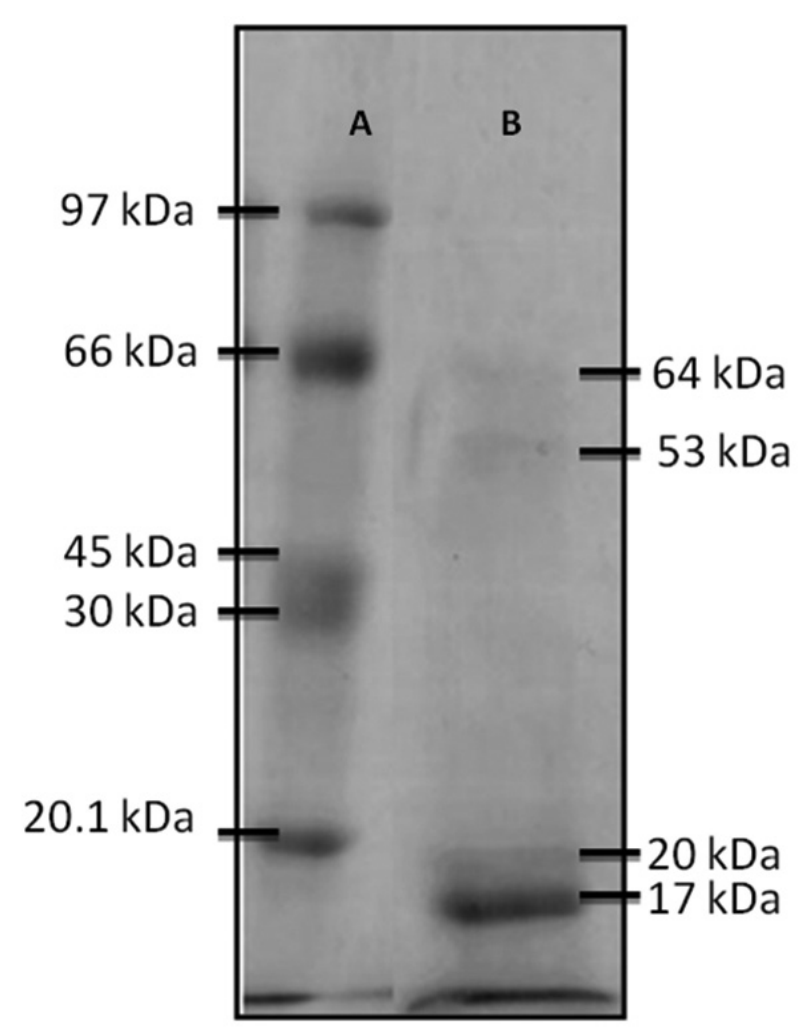

Figure 3. Electrophoretic profile of the enzyme obtained from the latex of quixaba. "A" = bands formed by protein standards and "B" = bands formed by proteins from the quixaba latex.

purified in these other studies, and purified proteases likely differ greatly from those derived from crude plant extracts such as the quixaba latex used in this research.

\section{Conclusions}

The latex of the quixaba plant is a potential source for a milk-clotting protease. The best performance as a milk-clotting agent was achieved at alkaline $\mathrm{pH}$ and temperatures above $40^{\circ} \mathrm{C}$. The protease was stable at room temperature and at various tested $\mathrm{pH}$ values, evidencing that the quixaba latex is a possible alternative to animal rennet for the production of cheese. Future studies can further explore this new research avenue.

\section{Acknowledgments}

The authors would like to thank FACEPE, CNPq and CAPES (PROCAD/NF 2009 Process 0921/2010) for their encouragement and for funding this research.

\section{References}

AHMED, I. A. M. et al. Characterisation of partially purified milkclotting enzyme from Solanum dubium Fresen seeds. Food Chemistry, v. 116, p. 395-400, 2009. http://dx.doi.org/10.1016/j. foodchem.2008.11.072

ALENCAR, R. B. et al. Alkaline proteases from digestive tract of four tropical fishes. Brazilian Journal of Food Technology, v. 6, p. 279-284, 2003.
ARIMA, K.; YU, J.; IWASAKI, S. Milk-clotting enzyme from Mucor pusillus var. Lindt. Methods in Enzymology, v. 19, p. 446-459, 1970. http://dx.doi.org/10.1016/0076-6879(70)19033-1

BALCONES, E.; OLANO, A.; CALVO, M. M. Factors affecting the rennet clotting properties of ewe's milk. Journal of Agriculture and Food Chemistry, v. 44, p. 1993-1996, 1996. http://dx.doi. org/10.1021/jf960138u

BRADFORD, M. M. A. Rapid and sensitive method for the quantitation of microgram quantities of protein utilizing the principle of proteindye binding. Analytical Biochemistry, v. 72, p. 248-254, 1976. http://dx.doi.org/10.1016/0003-2697(76)90527-3

CAVALLI, S. V. et al. Hydrolysis of caprine and ovine milk proteins, brought about by aspartic peptidases from Silybum marianum flowers. Food Chemistry, v. 106, p. 997-1003, 2008. http://dx.doi. org/10.1016/j.foodchem.2007.07.015

CHAZARRA, S. et al. Characterization of the milk-clotting properties of extracts from artichoke (Cynara scolymus, L.) flowers. International Dairy Journal, v. 17, p. 1393-1400, 2007. http:// dx.doi.org/10.1016/j.idairyj.2007.04.010

DEMIR, Y. et al. Identification of protease from Euphorbia amygdaloides latex and its use in cheese production. Preparative Biochemistry and Biotechnology, v. 35, p. 291-299, 2005. PMid:16239194. http:// dx.doi.org/10.1080/10826060500218107

DEMIR, Y. et al. Cysteine protease (capparin) from capsules of Caper (Capparis spinosa). Food Technology and Biotechnology, v. 46, n. 3, p. 286-291, 2008.

DEVARAJ, K. B.; GOWDA, L. R.; PRAKASH, V. An unusual thermostable aspartic protease from the latex of Ficus racemosa (L.). Phytochemistry, v. 69, p. 647-655, 2008. PMid:17936863. http:// dx.doi.org/10.1016/j.phytochem.2007.09.003

DUARTE, A. R. et al. Jacaratia corumbensis O. Kuntze a new vegetable source for milk-clotting enzymes. Brazilian Archieves of Biology and Technology, v. 52, p. 1-9, 2009. http://dx.doi. org/10.1590/S1516-89132009000100001

DUBEY, V. K.; JAGANNADHAM, M. V. Procerain, a stable cysteine protease from the latex of Calotropis procera. Phytochemistry, v. 62 , n. 7, p. 1057-1071, 2003. http://dx.doi.org/10.1016/S00319422(02)00676-3

DYBOWSKA, E.; FUJIO, Y. Effect of temperature and gluconodlactone GDL concentration on milk aggregation and gelation process as revealed by optical method. Milchwissenschaft, v. 51, p. 557-560, 1996.

EGITO, A. S. et al. Milk-clotting activity of enzyme extracts from sunflower and albizia seeds and specific hydrolysis of bovine k-casein. International Dairy Journal, v. 17, p. 816-825, 2007. http://dx.doi.org/10.1016/j.idairyj.2006.09.012

FAMELART, M. H.; LE GRAET, Y.; RAULOT, K. Casein micelle dispersions into water, $\mathrm{NaCl}$ and $\mathrm{CaCl}_{2}$ : physicochemical characteristics of micelles and rennet coagulation. International Dairy Journal, v. 9, p. 293-297, 1999. http://dx.doi.org/10.1016/ S0958-6946(99)00077-1

FERRAZ, J. S.; ALBUQUERQUE, U. P.; MEUNIER, I. M. J. Valor de uso e estrutura da vegetação lenhosa às margens do riacho do Navio, Floresta, PE, Brasil. Acta Botânica Brasílica, v. 20, p. 125-134, 2006. http://dx.doi.org/10.1590/S0102-33062006000100012

FOX, P. F. Advanced dairy chemistry: proteins. 3rd ed. London: Blackie Academic \& Professional, 1997. v. 1.

GALAN, E. et al. Influence of Different Amounts of Vegetable Coagulant from Cardoon Cynara cardunculus and Calf rennet on the proteolysis and sensory characteristics of cheese made with sheep 
milk. International Dairy Journal, v. 18, p. 93-98, 2008. http:// dx.doi.org/10.1016/j.idairyj.2007.06.003

GUPTA, R.; BEG, Q. K.; LORENZ, P. Bacterial alkaline proteases: molecular approaches and industrial applications. Applied Microbiology and Biotechnology, v. 59, p. 15-32, 2002. PMid:12073127. http://dx.doi.org/10.1007/s00253-002-0975-y

HARBOE, M. K.; BUDTZ, P. The production, action and application of rennet and coagulants. Technology of Cheesemaking. Sheffield: Academic Press, 1999. p. 33-65.

HASHIM, A. B. et al. Ginger rhizome as a potential source of milk coagulating cysteine protease. Phytochemistry, v. 72, p. 458-464. 2011. PMid:21353685. http://dx.doi.org/10.1016/j. phytochem.2010.12.002

JAROS, D.; SEITLER, K.; RAHM, H. Enzymatic coagulation of milk: animal rennets and microbial coagulants differ in their gelation behaviour as affected by $\mathrm{pH}$ and temperature. International Journal of Food Science and Technology, v. 43, p. 1721-1727, 2008. http:// dx.doi.org/10.1111/j.1365-2621.2008.01749.x

KETHIREDFFIPALI, P.; HILL, A. R.; DALGLEISH, D. G. Protein interactions in heat-treated milk and effect on rennet coagulation. International Dairy Jounal, v. 20, p. 838-843, 2010. http://dx.doi. org/10.1016/j.idairyj.2010.06.003

LAEMMLI, U. K. Cleavage of structural proteins during the assembly of the head of bacteriophage T4. Nature, v. 227, p. 680-685, 1970. PMid:5432063. http://dx.doi.org/10.1038/227680a0

LO PIERO, A. R.; PUGLISI, I.; PETRONE, G. Characterization of "lettucine", a serine-like protease from Lactua sativa leaves, as a novel enzyme for milk-clotting. Journal of Agricultural and Food Chemilcal, v. 50, p. 2439-2443, 2002. PMid:11929310. http://dx.doi. org/10.1021/jf011269k

LORENZI, H.; MATOS, J. A. Plantas medicinais no Brasil. Nativas e Exóticas. Nova Odessa: Instituto Plantarum, 2002. p. 432-433.

MENON, M. et al. Isolation and characterization of proteolytic enzymes from the latex of Synadenium grantii Hook, 'f'. Plant Science, v. 163, p. 131-139, 2002. http://dx.doi.org/10.1016/S0168-9452(02)00085-7

MOREIRA, K. A. et al. New alkaline protease from Nocardiopsis sp.: partial purification and characterization. Process Biochemistry, v. 39, p. 67-72, 2003. http://dx.doi.org/10.1016/S00329592(02)00312-6

NÁJERA, A. I.; DE RENOBALES, M.; BARRON, L. J. R. Effects of $\mathrm{pH}$, temperature, $\mathrm{CaCl}_{2}$ and enzyme concentrations on the rennet-clotting properties of milk: a multifactorial study. Food Chemistry, v. 80, p. 345-352, 2003. http://dx.doi.org/10.1016/ S0308-8146(02)00270-4

NEVES-SOUZA, R. D.; SILVA, R. S. S. F. Study of cost and yield of minas like fresh cheese produced with added fat free soybean hydro- soluble extract powder with curd formed by different coagulants agents. Ciência e Tecnologia de Alimentos, v. 25, n. 1, p. 170-174, 2005. http://dx.doi.org/10.1590/S0101-20612005000100028

ORDÓÑEZ, J. A. et al. Tecnologia de Alimentos. Alimentos de Origem Animal. Porto Alegre: Artmed, 2005. v. 2, p. 85-103.

PERRY, K. S. P. Queijos: aspectos químicos, bioquímicos e microbiológicos. Química Nova, v. 27, p. 293-300, 2004. http:// dx.doi.org/10.1590/S0100-40422004000200020

PICÓN, A.; MEDINA, M.; NUÑEZ, M. Prediction of clotting time for milk coagulation by mixtures of proteolytic enzymes. Food Chemistry, v. 52, p. 411-414, 1995. http://dx.doi.org/10.1016/03088146(95)93291-X

PRADOS, F.; PINO, A.; FERNÁNDEZ-SALGUERO, J. Effect of a powdered vegetable coagulant from Cynara cardunculus in the accelerated ripening of Manchego cheese. International Journal of Food Science and Technology, v. 42, p. 556-561, 2007. http:// dx.doi.org/10.1111/j.1365-2621.2006.01271.x

RAO, M. B. et al. Molecular and biotechnological aspects of microbial proteases. Microbiology and Molecular Biology Reviews, v. 62, p. 597-635, 1998. PMid:9729602 PMCid:PMC98927.

RAPOSO, S.; DOMINGOS, A. Purification and characterization of milk-clotting aspartic proteinases from Centaura calciptrea cell suspension cultures. Process Biochemistry, v. 43, p. 139-144, 2008. http://dx.doi.org/10.1016/j.procbio.2007.11.003

SILVA, K. B. et al. Caracterização morfológica de frutos, sementes e germinação de Sideroxylon obtusifolium (Roem. E Schult.) Penn. (Sapotaceae). Revista Arvore, v. 36 p. 59-64, 2012. http://dx.doi. org/10.1590/S0100-67622012000100007

TRIPATHI, P.; TOMAR, R.; JAGANNADHAM, M. V. Purification and biochemical characterisation of a novel protease streblin. Food Chemistry, v. 125, p. 1005-1012, 2011. http://dx.doi.org/10.1016/j. foodchem.2010.09.108

VAN HOOYDONK, A. C. M.; HAGEDOORN, H. G.; BOERRIGTER, I. J. The effect of various cations on the renneting of milk. Netherlands Milk and Dairy Journal, v. 40, p. 369-390, 1986.

VASCONCELOS, M. P.; ARAÚJO, K. G. L.; VERRUMA-BERNARDI, M. R. Efeito do $\mathrm{pH}$ do leite e do tipo de coalho sobre o rendimento de massa na produção de queijos. Revista Brasileira de Agrociência, v. 10, p. 499-502, 2004.

VISHWANATHA, K. S.; APPU RAO, A. G.; SINGH, S. A. Production and characterization of a milk-clotting enzyme from Aspergillus oryzae MTCC 5341. Applied Microbiology and Biotechnology, v. 85 , p. $1849-1859,2010$. PMid:19727708. http://dx.doi. org/10.1007/s00253-009-2197-Z

YOUSIF, B. H.; McMAHON, D. J.; SHAMMET, K. M. Milk-clotting. Enzyme from Solanum dobium plant. Journal of dairy, v. 6, p. 637644, 1996. 